\title{
Paw-shake response and locomotion: can one CPG generate two different rhythmic behaviors?
}

\author{
Alexander N Klishko ${ }^{1 *}$, David Cofer ${ }^{2}$, Gennady Cymbalyuk ${ }^{2}$, Donald H Edwards ${ }^{2}$, Boris I Prilutsky ${ }^{1}$ \\ From Twenty First Annual Computational Neuroscience Meeting: CNS*2012 \\ Decatur, GA, USA. 21-26 July 2012
}

Rhythmic limb movements like locomotion or paw-shake response are controlled by network of spinal circuits, known as central pattern generators (CPGs), as evidenced from locomotor-like and paw-shake like activity in limb peripheral nerves elicited in decerebrate or spinal animals with blocked neuromuscular transmission [4]. Unlike fictive locomotion and scratch, that are likely controlled by distinct CPGs [3], fictive paw-shake response has not been systematically investigated and it is not known whether it is controlled by a specialized CPG or by the CPG that also controls locomotion. In-vivo recordings of paw-shake motor patterns elicited by stimulation of paw skin afferents [7] have revealed high frequency hindlimb oscillations $(\sim 10 \mathrm{~Hz})$ with atypical muscle synergies - reciprocal activation of anterior and posterior hindlimb muscles in each half of the paw-shake cycle; both anterior and posterior muscle groups include flexor and extensor muscles. We asked whether a paw-shake response with the atypical muscle synergies can be generated by a typical half-center locomotor CPG reciprocally activating flexor and extensor muscles.

Using software AnimatLab [2] we developed a 5-segment cat hindlimb model with 12 Hill-type muscle actuators controlled by (1) a half-center CPG activating flexor and extensor muscles (two-joint muscles received both flexion- and extension-related signals $[5,6])$ and (2) proprioceptive input originated from the muscle spindle and Golgi tendon organ afferents. The CPG was modeled by two single-compartment spiking neurons in a half-center configuration. Other neurons (Ia-afferents, alpha-motor neurons, Ia-interneurons, and interneurons mediating autogenic and heterogenic reflex pathways) were modeled as non-spiking neurons (firing rate model based on work

\footnotetext{
* Correspondence: aklishko3@gatech.edu

'Center for Human Movement Studies, School of Applied Physiology,

Georgia Institute of Technology, Atlanta, GA, USA

Full list of author information is available at the end of the article
}

by [1]). Model parameters were adjusted such that computer simulations reproduced the recorded paw-shake mechanics and the anterior-posterior muscle activation patterns.

The obtained results demonstrated that a half-center locomotor CPG can produce movement mechanics and muscle activity patterns typical for paw-shake responses if (1) the locomotor CPG is capable to operate at frequencies 3 to10 times higher than during locomotion and (2) synaptic weights in spinal circuits can be modified during paw-shake response. We speculate that the two conditions can be realized by sensory input from paw skin afferents.

\section{Acknowledgements \\ Supported by NIH grants: HD-032571, NS-048844, EB012855}

\section{Author details}

'Center for Human Movement Studies, School of Applied Physiology, Georgia Institute of Technology, Atlanta, GA, USA. ${ }^{2}$ Neuroscience Institute, Georgia State University, Atlanta, GA, USA.

Published: 16 July 2012

\section{References}

1. Beer RD, San Diego: Intelligence as adaptive behavior: an experiment in computational neuroethology. Academic Press; 1990.

2. Cofer D, Cymbalyuk G, Reid J, Zhu Y, Heitler WJ, Edwards DH: AnimatLab: a 3D graphics environment for neuromechanical simulations. J. Neurosci Methods 2010, 187:280-288.

3. Frigon A, Gossard JP: Evidence for specialized rhythm-generating mechanisms in the adult mammalian spinal cord. J Neurosci 2010, 30:7061-7071.

4. Pearson KG, Rossignol S: Fictive motor patterns in chronic spinal cats. J Neurophysiol 1991, 66:1874-1887.

5. Perret C, Cabelguen JM: Main characteristics of the hindlimb locomotor cycle in the decorticate cat with special reference to bifunctional muscles. Brain Res 1980, 187:333-352.

6. Prilutsky Bl: Coordination of two- and one-joint muscles: functional consequences and implications for motor control. Motor Control 2000, 4:1-44.

7. Smith JL, Hoy MG, Koshland GF, Phillips DM, Zernicke RF: Intralimb coordination of the paw-shake response: a novel mixed synergy. J Neurophysiol 1985, 54:1271-1281. 
doi:10.1186/1471-2202-13-S1-P70

Cite this article as: Klishko et al.: Paw-shake response and locomotion: can one CPG generate two different rhythmic behaviors? BMC

Neuroscience 2012 13(Suppl 1):P70.

Submit your next manuscript to BioMed Central and take full advantage of:

- Convenient online submission

- Thorough peer review

- No space constraints or color figure charges

- Immediate publication on acceptance

- Inclusion in PubMed, CAS, Scopus and Google Scholar

- Research which is freely available for redistribution

Submit your manuscript at 